\title{
DINAMIKA PERDAGANGAN BERAS VIETNAM
}

(Dynamics of Vietnam Rice Trade)

\author{
Agus Dwi Nugroho ${ }^{1}$, Jamhari $^{2}$, Jangkung Handoyo Mulyo ${ }^{3}$
}

\begin{abstract}
The aims of this study is to analyze the performance of export-import, competitiveness and the factors affecting export-import of Vietnam rice. Type of data used is secondary data of 1980-2009. To determine the fluctuation of export-import trade were applied trend and trade specialization ratio. To find out the analysis of competitiveness were run revealed comparative advantage (RCA) and accelaration ratio (AR). To investigate the factors affecting the export and import used error correction model (ECM). Vietnam export trend showed an increase and imports trend showed a decline and in the maturity stage. Vietnam has high competitiveness but the exports acceleration is low. Vietnam's export affected by per capita rice availability and the exchange rate while imports of Vietnam affected by the production, world rice prices and real national income.
\end{abstract}

Keyword : rice, trade, trend, competitiveness

\section{INTISARI}

Penelitian ini bertujuan menganalisis kinerja ekspor-impor, daya saing dan faktor yang mempengauhi ekspor-impor beras Vietnam. Jenis data yang digunakan data sekunder tahun 1980-2009. Untuk mengetahui perkembangan ekspor-impor menggunakan trend dan trade specialization ratio. Untuk mengetahui daya saing menggunakan analisis revealed comparative advantage (RCA) dan accelaration ratio (AR). Untuk mengetahui faktor yang mempengaruhi ekspor dan impor menggunakan error correction model (ECM). Tren ekspor Vietnam menunjukkan peningkatan sebaliknya impor menunjukkan penurunan dan dalam tahapan kematangan. Beras Vietnam memiliki daya saing tinggi namun percepatan ekspornya rendah. Ekspor Vietnam dipengaruhi ketersediaan per kapita dan nilai tukar US\$ dolar terhadap dong sedangkan impor Vietnam dipengaruhi produksi, harga beras dunia dan pendapatan nasional riil.

Kata kunci : beras, tren perdagangan, daya saing

\section{PENDAHULUAN}

Perdagangan internasional sangat dibutuhkan oleh negara-negara di dunia karena secara teori perdagangan internasional akan meningkatkan kesejahteraan negara-negara yang melakukan perdagangan karena melalui perdagangan akan terjadi peningkatan efisiensi penggunaan sumberdaya domestik dan akses pasar ke negara lain.

Dalam teori perdagangan internasional disebutkan bahwa faktor-faktor yang mempengaruhi ekspor dapat dilihat dari sisi permintaan (faktor eksternal) dan sisi penawaran (faktor internal). Dari sisi permintaan, ekspor dipengaruhi oleh harga ekspor, nilai tukar riil, pendapatan dunia dan kebijakan devaluasi. Sementara dari sisi penawaran, ekspor dipengaruhi oleh harga ekspor, harga domestik, nilai tukar riil, kapasitas produksi yang dapat diproduksi meialui investasi, impor bahan baku dan kebijakan deregulasi (Salvatore, 1993). 
Konsep keunggulan dalam perdagangan internasional merupakan hal yang sangat penting. Konsep keunggulan dalam teori klasik perdagangan internasional ada 2 , yakni (Salvatore, 1993) :

\section{a. Keunggulan absolut}

Teori ini disusun oleh Adam Smith atas dasar efisiensi. Apabila suatu negara melakukan spesialisasi sehingga mampu tercipta efisiensi untuk suatu produk A namun tidak mampu menciptakan efisiensi untuk produk B, maka negara tersebut akan melakukan perdagangan. Negara yang memiliki spesialisasi komoditas A akan mengekspor komoditas A serta akan mengimpor komoditas B dari negara lain. Dalam hal ini, negara tersebut memiliki keunggulan absolut untuk produk $\mathrm{A}$ namun tidak memiliki keunggulan absolut untuk produk B. Prinsip ini hampir sama dengan perilaku individu. Individu akan menghasilkan suatu barang secara efisien sehingga barang tersebut akan ditukarkan dengan barang lain yang dibutuhkan.

Prinsip keunggulan absolut akan berjalan apabila kedua pihak memperoleh keuntungan (gain) dari perdagangan. Apabila salah satu pihak tidak memperoleh keuntungan maka proses perdagangan tidak akan berjalan.

b. Keunggulan komparatif

Hukum keunggulan komparatif diungkapkan oleh David Ricardo. Hukum keunggulan komparatif merupakan perbaikan dari kelemahan keunggulan absolut yang diungkapkan Adam Smith. Apabila sebuah negara tidak mampu menghasilkan dua buah produk yang efisien dibandingkan negara lain, maka negara tersebut dapat melakukan spesialisasi untuk sebuah produk sehingga negara tersebut mampu meningkatkan keunggulan komparatif untuk produk pertama. Sedangkan untuk produk kedua, negara tersebut tidak dapat melakukan spesialisasi sehingga harus tetap mengimpor dari negara lain.

Teori perdagangan internasional yang baru dikemukakan oleh Porter dengan model berlian. Menurut Porter dan beberapa pakar lainnya mengungkapkan hal-hal yang harus dimiliki atau dikuasai oleh setiap perusahaan atau negara untuk meningkatkan keunggulan kompetitifnya adalah terutama teknologi, tingkat kewirausahaan yang tinggi, tingkat efisiensi atau produktivitas yang tinggi, kualitas tinggi dari produk yang dibuat, promosi yang luas dan agresif, pelayanan purna jual yang baik, tenaga kerja dengan tingkat keterampilan/pendidikan, etos kerja, disiplin, komitmen, kreativitas dan motivasi yang tinggi, proses produksi mempunyai skala ekonomis, diferensial produk, modal dan prasarana serta sarana lainnya yang cukup, jaringan distribusi di dalam dan terutama di luar negeri yang luas dan diorganisasikan serta dikelola secara profesional, proses produksi dilakukan dengan sistem full in time. Faktor keunggulan kompetitif ini saat ini semakin penting terutama di pasar internasional dengan persaingan yang semakin tidak sempurna (Tambunan, 2004).

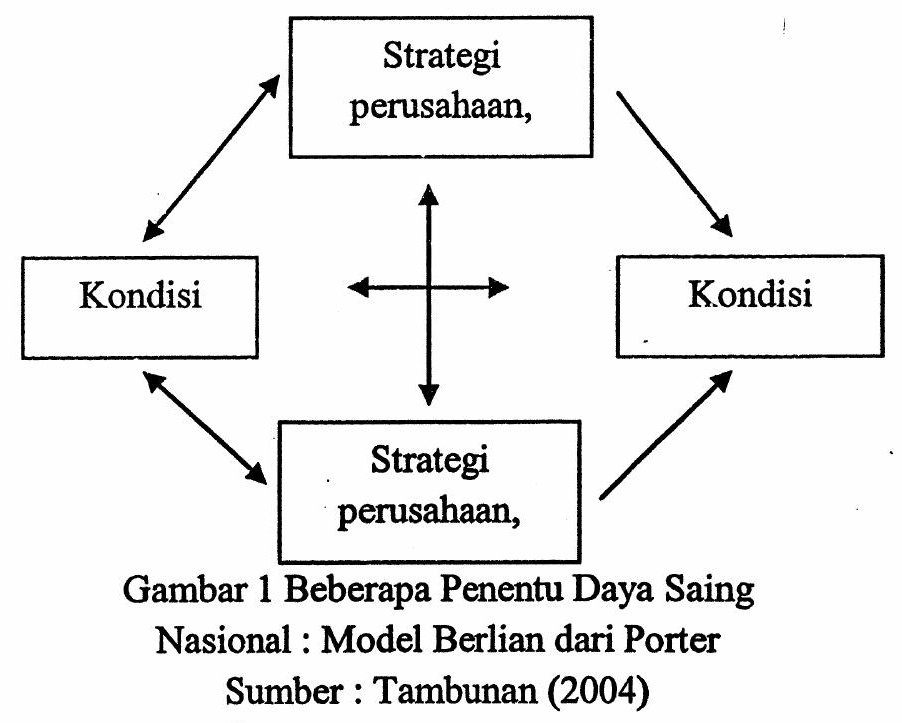


Proses globalisasi ekonomi bidang pertanian di dunia sudah sangat maju dengan munculnya tatanan kebijakan yang dikeluarkan oleh berbagai organisasi perdangangan. Kebijakan tersebut terutama berkaitan erat dengan kegiatan ekspor impor bidang pertanian. Kegiatan ekspor impor meliputi hampir semua komoditas pertanian, salah satunya adalah beras.

Produksi beras dunia pada tahun 2009 mengalami penurunan karena adanya perubahan iklim sehingga banyak wilayah pertanaman padi yang gagal panen, baik karena bencana alam maupun serangan hama penyakit. Penurunan produksi beras tidak menyebabkan adanya penurunan cadangan stok beras dunia bahkan jumlah stok beras dunia tahun 2009 lebih tinggi daripada tahun 2007. Stok beras dunia meningkat 16,5 juta ton selama tiga tahun yakni dari 75 juta ton pada 2006 menjadi 91,5 juta ton pada 2009. Peningkatan ini terjadi karena adanya peningkatan cadangan beras di Cina, India, Indonesia dan Thailand (FAO, 2012).

Harga beras dunia pada tahun 2011 mengalami kenaikan dua kali lipat apabila dibandingkan harga beras tahun 2006. Keadaan ini mempengaruhi perdagangan beras di Asia karena produksi beras yang terpusat di Asia juga diikuti dengan kegiatan ekspor impor beras dunia yang hampir sebagian besar terkonsentrasi juga di Asia. Negara eksportir beras yang terpenting diantaranya adalah Thailand, Vietnam, India, Pakistan dan China. Kelima negara Asia ini mengambil pangsa ekspor dunia sebesar 75\% pada 2004. Pangsa impor Asia mencapai sekitar 45\% dari beras yang diperdagangkan di pasar dunia, selebihnya tersalurkan ke benua lain terutama ke Afrika dan Amerika Tengah. Negara importir beras yang terbesar di Asia adalah Filipina, Bangladesh, Indonesia, Iran, Irak,
Jepang, Malaysia dan Korea Selatan (Sawit dan Rusastra, 2005).

Ekspor beras negara-negara di dunia pada tahun 2009 dan 2010 dikuasai oleh 5 negara. Eksportir beras terbesar di dunia adalah Thailand dan urutan selanjutnya adalah Vietnam, AS, Pakistan, India dan Cina. Ekspor beras dunia pada tahun 2010 mengalami peningkatan karena adanya peningkatan permintaan beras dari negara-negara Asia terutama Filipina. Permintaan beras dari Brazil dan AS akan meningkat untuk memenuhi kebutuhan rakyat Afrika. Sementara ekspor beras dari Thailand, Cina, Myanmar dan Vietnam akan meningkat pula sebagai. kompensasi atas turunnya produksi beras Kamboja, AS dan Uruguay. India yang merupakan negara produsen beras kedua di dunia, pada tahun 2010 tidak terlalu berperan pada perdagangan beras karena India berkomitmen untuk memenuhi seluruh kebutuhan beras dalam negeri agar mampu mengurangi impor (FAO, 2012).

Keadaan pasar beras dunia sangatlah tidak stabil. Menurut Amang dan Hussein (2001), sejumlah negara eksportir beras, misal Thailand, Cina, India dan Pakistan sering menahan ekspor beras apabila produksi beras dalam negerinya berkurang dan risiko ketahanan pangan meningkat. Hal ini akan berpengaruh besar pada persediaan beras dunia.

Kondisi pasar beras yang bersifat tipis sangat menarik apabila dihubungkan dengan wilayah Asia Tenggara mengingat kawasan ini merupakan salah satu pusat produksi maupun konsumsi beras dunia. Di satu sisi, negara kawasan Asia Tenggara berusaha meningkatkan produksi pangan melalui investasi di bidang pertanian, termasuk kerja sama di bidang penelitian dan inovasi. Namun di sisi lain, pertumbuhan jumlah penduduk yang cepat 
di Asia Tenggara menjadi ancaman serius bagi ketersediaan pangan dunia.

Dengan melihat besarnya peran beras dalam perekonomian negara-negara di Asia Tenggara dan berbagai faktor yang mempengaruhi kebijakan ekspor impor, maka menjadi suatu hal menarik untuk mempelajari bagaimana kegiatan perdagangan beras di Asia Tenggara terutama mengenai ekspor impor, terutama di negara Vietnam. Vietnam pada awal tahun 80'an merupakan negara importir namun dengan adanya reformasi ekonomi maka Vietnam mampu berubah menjadi negara eksportir.
Penelitian ini mempunyai tujuan (1) menganalisis kinerja ekspor dan impor beras Vietnam, (2) menganalisis daya saing beras Vietnam dan (3) mengetahui faktor-faktor yang mempengaruhi ekspor impor beras Vietnam

\section{METODE PENELITIAN}

Jenis dan Sumber Data

Jenis data yang digunakan dalam penelitian ini adalah data sekunder dari tahun 1980-2009. Jenis data dan sumber data dalam penelitian ini pada tabel 1.

Tabel 1 Sumber Data dan Jenis Data yang Digunakan dalam Penelitian

\begin{tabular}{|c|c|c|}
\hline No & Jenis Data & Sumber Data \\
\hline 1 & $\begin{array}{l}\text { volume ekspor dan impor beras Vietnam, produksi beras } \\
\text { Vietnam, harga beras ekspor dan impor Vietnam, luas lahan, } \\
\text { jumlah bibit, jumlah tenaga kerja dan jumlah traktor }\end{array}$ & FAO \\
\hline 2 & $\begin{array}{l}\text { nilai tukar mata uang Vietnam terhadap dollar AS dan jumlah } \\
\text { pupuk }\end{array}$ & IRRI \\
\hline 3 & jumlah penduduk Vietnam & International Data Base \\
\hline 4 & harga beras dunia & Index Mundi \\
\hline 5 & pendapatan per kapita Vietnam & Comtrade UN \\
\hline
\end{tabular}

Untuk mengetahui perkembangan ekspor beras Vietnam menggunakan persamaan tren:

$$
E=a+b T
$$

dimana $\mathrm{E}$ adalah jumlah ekspor beras Vietnam, $\mathrm{A}$ adalah intersep, $\mathrm{b}$ adalah koefisien regresi pengubah waktu dan $\mathrm{T}$ adalah waktu

Sedangkan analisis tren impor beras Vietnam:

$$
\mathrm{I}=\mathrm{a}+\mathrm{bT}
$$

dimana I adalah jumlah impor beras Vietnam, $A$ adalah intersep, $b$ adalah koefisien regresi pengubah waktu dan $\mathrm{T}$ adalah waktu

Untuk mengetahui net ekspor digunakan analisis dimana $\mathrm{N}$ adalah net ekspor, $\mathrm{E}_{\mathrm{i}}$ adalah total nilai ekspor produk $\mathrm{i}, \mathrm{I}_{\mathrm{i}}$ adalah total nilai impor produk $i$.

Untuk mengetahui daya saing beras Vietnam maka menggunakan analisis RCA dan AR

$$
\mathrm{RCA}=\frac{\mathrm{X}_{\mathrm{ij}} / X_{. j}}{\mathrm{X}_{i w} / X_{. w}}
$$

dimana $X_{i j}$ adalah nilai ekspor komoditas beras negara Vietnam, $X_{\mathbf{j}}$ adalah nilai ekspor total negara Vietnam, $\mathrm{X}_{\mathrm{iw}}$ adalah nilai ekspor komoditas beras dunia dan $\mathrm{X}_{\mathrm{w}}$ adalah nilai ekspor total dunia 


$$
A R=\frac{\left(\operatorname{tren} X_{i j}\right)+100}{\left(\operatorname{tren} X_{i w}\right)+100}
$$

dimana $X_{i j}$ adalah nilai ekspor komoditas beras negara Vietnam, $X_{\text {iw }}$ adalah nilai ekspor komoditas beras dunia, $A R \geq 1$ maka Vietnam mengalami percepatan pertumbuhan dan memiliki keunggulan komparatif untuk komoditas beras, $\mathrm{AR}<1$ maka Vietnam tidak mengalami percepatan pertumbuhan dan tidak memiliki keunggulan komparatif untuk komoditas beras

Untuk mengetahui faktor yang mempengaruhi ekspor dan impor beras Vietnam maka digunakan analisis koreksi kesalahan (Error Corection Model/ECM). Tahapan dari analisis ECM adalah sebagai berikut

\section{a. Uji Stasioneritas}

Analisis regresi sebaiknya tidak dilakukan apabila data yang digunakan tidak stasioner karena akan menghasilkan regresi meragukan. Suatu data disebut stasioner apabila nilai rata-rata mean dan varians koristan selama periode pengamatan (Gujarati, 2003). Uji stasioneritas data dilakukan dengan uji akar-akar unit (unit root test) dan uji derajat integrasi (integration test).

\section{b. Uji Akar-akar Unit (Unit root test)}

Konsep yang banyak digunakan untuk menguji kestasioneran data adalah uji akar unit. Untuk menguji perilaku data pada penelitian dapat memakai uji Dickey-Fuller (DF) sebagai berikut (Gujarati, 2003) :

$$
\mathrm{DX}_{\mathrm{t}}=\mathrm{a}_{0}+\mathrm{a}_{1} \mathrm{BX}_{\mathrm{t}}+\sum_{t}^{k} b k \mathrm{~B}^{\mathrm{k}} \mathrm{DX}_{\mathrm{t}}
$$

dimana $\mathrm{DX}_{\mathrm{t}}$ adalah $\mathrm{X}_{\mathrm{t}}-\mathrm{X}_{\mathrm{t}-1,}, \mathrm{~B}$ adalah operasi kelambanan (backward lag operator), $\mathrm{X}_{\mathrm{t}}$ adalah variabel yang diamati pada periode $\mathrm{t}$

Hipotesis uji akar unit

$\mathrm{H}_{0}: \beta=0$, rangkaian data $(\mathrm{Pt})$ bersifat tidak stasioner

$\mathrm{H}_{1}: \beta \neq 0$, rangkaian data $(\mathrm{Pt})$ bersifat stasioner dengan kriteria pengujian apabila probabilitas $\mathrm{DF} \geq 0,05$ maka $\mathrm{H}_{0}$ diterima probabilitas $\mathrm{DF}<0,05$ maka $\mathrm{H}_{0}$ ditolak

\section{c. Uji Derajat Integrasi (Integration test) \\ Uji derajat integrasi merupakan} kelanjutan dari uji akar-akar unit dan hanya diperlukan apabila seluruh datanya belum stasioner pada derajat nol atau 1 (0). Untuk melakukan uji ini digunakan uji Dickey Fuller (DF) sebagai berikut (Gujarati, 2003) :

$$
\mathrm{D}^{2} \mathrm{X}_{\mathrm{t}}=\mathrm{e}_{0}+\mathrm{e}_{1} \mathrm{BDX}_{\mathrm{t}}+\sum_{t}^{k} f k \mathrm{~B}^{\mathrm{k}} \mathrm{D}^{2} \mathrm{X}_{\mathrm{t}}
$$

dimana $\mathrm{D}^{2} \mathrm{X}_{\mathrm{t}}$ adalah (1-B) $\mathrm{DX}_{\mathrm{t}}, \mathrm{BDX}_{\mathrm{t}}$ adalah $\mathrm{DX}_{\mathrm{t}-1}, \mathrm{X}_{\mathrm{t}}$ adalah variabel yang diamati pada periode $t$

Hipotesis uji integrasi

$\mathrm{H}_{0}: \beta=0$, rangkaian data $(\mathrm{Pt})$ bersifat tidak stasioner

$\mathrm{H}_{1}: \beta \neq 0$, rangkaian data $(\mathrm{Pt})$ bersifat stasioner

dengan kriteria pengujian apabila probabilitas $\mathrm{DF} \geq 0,05$ maka $\mathrm{H}_{0}$ diterima

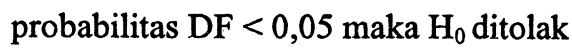

\section{d. Uji Kointegrasi (Cointegration approach) \\ Uji kointegrasi merupakan lanjutan} dari uji akar-akar unit dan uji derajat integrasi. Uji kointegrasi dimaksudkan untuk mengetahui perilaku data dalam jangka panjang antar variabel terkait apakah berkointegrasi atau 
tidak seperti yang dikehendaki oleh teori ekonomi. Hipotesis uji kointegrasi

$\mathrm{H}_{0}: \beta=0$, rangkaian data $(\mathrm{Pt})$ terdapat tidak terkointegrasi

$\mathrm{H}_{1}: \beta \neq 0$, rangkaian data $(\mathrm{Pt})$ bersifat terkointegrasi

dengan kriteria pengujian apabila trace statistics $\leq 0,05$ maka $\mathrm{H}_{0}$ diterima trace statistics $>0,05$ maka $\mathrm{H}_{0}$ ditolak

\section{c. Model Koreksi Kesalahan (Error Correction Model)}

Variabel ekspor (E) untuk negara Vietnam diduga dipengaruhi oleh variabel independen (X) antara lain ketersediaan beras per kapita, harga beras ekspor, harga beras dunia $f o b$ Thailand, nilai tukar nominal, efisiensi input produksi dan dummy AFTA. Model ekspor Vietnam untuk jangka panjang adalah

$$
\mathrm{E}=\beta_{0}+\beta_{1} \log \mathrm{X}_{1}+\beta_{2} \log \mathrm{X}_{2}+\beta_{3}
$$$$
\log X_{3}+\beta_{4} \log X_{4}+\beta_{5} \log X_{5}+D+e
$$

dimana $\mathrm{E}$ adalah ekspor, $\mathrm{X}_{1}$ adalah ketersediaan beras per kapita (ton/jiwa), $X_{2}$ adalah harga beras ekspor (US\$/ton), $\mathrm{X}_{3}$ adalah harga beras dunia fob Thailand (US\$/ton), $\mathrm{X}_{4}$ adalah nilai tukar nominal, $\mathrm{X}_{5}$ adalah efisiensi input produksi, $\mathrm{D}$ adalah kebijakan AFTA $\mathrm{D}=$ 0 apabila kebijakan AFTA belum diterapkan D $=1$ apabila kebijakan AFTA telah diterapkan

Sedangkan model koreksi kesalahan ekspor beras dari Engle-Granger untuk jangka pendek sebagai berikut :

$\Delta \mathrm{E} \quad=\beta_{0}+\beta_{1} \Delta \log \mathrm{X}_{1}+\beta_{2} \Delta \log \mathrm{X}_{2}+\beta_{3}$ $\Delta \log X_{3}+\beta_{4} \Delta \log X_{4}+\beta_{5} \Delta \log X_{5}+D+\beta_{6}$ $\Delta \mathrm{EC}_{\mathrm{t}-1}+\mathrm{e}$

Hubungan antara variabel impor beras untuk negara Vietnam dengan ketersediaan beras per kapita, harga beras impor, harga beras dunia fob Thailand, pendapatan per kapita, nilai tukar nominal, efisiensi input produksi dan dummy AFTA dirumuskan dalam model dasar penelitian:

$$
\begin{aligned}
& \mathrm{I}=\beta_{0}+\beta_{1} \log X_{1}+\beta_{2} \log X_{2}+\beta_{3} \\
& \log X_{3}+\beta_{4} \log X_{4}+\beta_{5} \log X_{5}+\beta_{6} \log X_{6}+D \\
& +e
\end{aligned}
$$

dimana $I$ adalah impor, $X_{1}$ adalah ketersediaan beras per kapita (ton/jiwa), $\mathrm{X}_{2}$ adalah harga beras impor (US\$/ton), $\mathrm{X}_{3}$ adalah harga beras dunia fob Thailand (US\$/ton), $\mathrm{X}_{4}$ adalah pendapatan per kapita (US\$), $\mathrm{X}_{5}$ adalah nilai tukar nominal, $\mathrm{X}_{6}$ adalah efisiensi input produksi, $\mathrm{D}$ adalah kebijakan AFTA $\mathrm{D}=0$ apabila kebijakan AFTA belum diterapkan $\quad \mathrm{D}=1$ apabila kebijakan AFTA telah diterapkan

Sedangkan model koreksi kesalahan impor beras dari Engle-Granger dapat ditulis sebagai berikut :

$$
\begin{aligned}
& \Delta \mathrm{I} \quad=\beta_{0}+\beta_{1} \Delta \log \mathrm{X}_{1}+\beta_{2} \Delta \log \mathrm{X}_{2}+\beta_{3} \\
& \Delta \log \mathrm{X}_{3}+\beta_{4} \Delta \log \mathrm{X}_{4}+\beta_{5} \Delta \log \mathrm{X}_{5}+\beta_{6} \\
& \Delta \log \mathrm{X}_{6}+\mathrm{D}+\beta_{7} \Delta \mathrm{EC}_{\mathrm{t}-1}+\mathrm{e}
\end{aligned}
$$

Untuk mengetahui nilai efisiensi teknis setiap negara digunakan metode Data Envelopment Analysis (DEA). Penelitian ini menggunakan asumsi constant return to scale (CRS) dengan mengoptimalkan input yakni luas lahan, jumlah benih, jumlah pupuk dan jumlah tenaga kerja pertanian. Metode DEA adalah sebuah metode frontier non parametric yang menggunakan model program linier untuk menghitung perbandingan rasio output dan input untuk semua unit yang dibandingkan dalam sebuah populasi. Variabel input yang digunakan adalah jumlah bibit, jumlah pestisida, jumlah pupuk dan jumlah tenaga kerja pertanian di Vietnam tahun 1980-2009. 
Memaksimumkan DMU :

$\mathrm{E}_{\mathrm{k}}=\sum_{r=1}^{s} U_{r k} * Y_{r k}$

Dengan batasan atau kendala

$$
\begin{gathered}
\left(\sum_{r=1}^{s} U_{r k} * Y_{r j}\right)-\left(\sum_{i=1}^{m} V_{i k} * X_{r j}\right) \leq 0 ; \mathrm{j} \\
=1, \ldots \ldots \ldots, \mathrm{n} \\
\sum_{i=1}^{m} V_{i k} * X_{r j}=1
\end{gathered}
$$

Urk $\geq 0 ; r=1$,

Vrk $\geq 0 ; \mathrm{i}=1$, ., $\mathrm{s}$

dimana Yrk adalah jumlah output $r$ yang dihasilkan oleh sektor $\mathrm{k}$, Xik adalah jumlah input $\mathrm{i}$ yang diperlukan oleh sektor $\mathrm{k}$, Yrj adalah jumlah output $r$ yang dihasilkan oleh sektor $\mathbf{j}$, Xij adalah jumlah input $i$ yang diperlukan oleh sektor $j, s$ adalah jumlah sektor yang dianalisis, $m$ adalah jumlah input yang digunakan, Urk adalah bobot tertimbang dari output $r$ yang dihasilkan subsektor tanaman padi, Vik adalah bobot tertimbang dari input $\mathbf{i}$ yang dihasilkan subsektor tanaman padi, $E_{k}$ adalah nilai yang dioptimalkan sebagai indikator efisiensi relatif dari subsektor tanaman padi.

\section{Uji Asumsi Klasik}

1. Multikolinieritas

Multikolinieritas merupakan hubungan

linier antara variabel independen di dalam regresi berganda. Multikolinieritas dalam model regresi tidak mempengaruhi estimator

Tabel 2 Uji Statistik Durbin Watson d

\begin{tabular}{cl}
\hline Nilai statistik $\mathrm{d}$ & \multicolumn{1}{c}{ Hasil } \\
\hline $0<\mathrm{d}<\mathrm{d}_{\mathrm{L}}$ & Menolak hipotesisi nol; ada autokorelasi positif \\
$\mathrm{d}_{\mathrm{L}} \leq \mathrm{d} \leq \mathrm{d}_{\mathrm{U}}$ & Daerah keragu-raguan; tidak ada keputusan \\
$\mathrm{d}_{\mathrm{U}} \leq \mathrm{d} \leq 4-\mathrm{d}_{\mathrm{U}}$ & Menerima hipotesis nol; tidak ada autokorelasi positif/negative \\
$4-\mathrm{d}_{\mathrm{U}} \leq \mathrm{d} \leq 4-\mathrm{d}_{\mathrm{L}}$ & Daerah keragu-raguan; tidak ada keputusan \\
$4-\mathrm{d}_{\mathrm{L}} \leq \mathrm{d} \leq 4$ & Menolak hipotesisi nol; ada autokorelasi negative \\
\hline
\end{tabular}

sehingga estimator tetap bersifat BLUE. Namun estimator mempunyai varian dan kovarian yang besar sehingga sulit mendapatkan estimasi yang tepat. Hal ini menyebabkan nilai hitung uji $t$ akan kecil sehingga membuat variabel independen secara statistik tidak signifikan mempengaruhi variabel dependen walaupun nilai koefisien diterminasi $\left(\mathrm{R}^{2}\right)$ masih bisa relatif tinggi. Uji multikoliniearitas dalam penelitian ini menggunakan uji korelasi parsial antar variabel independen (Widarjono, 2010).

\section{Autokorelasi' \\ Autokorelasi merupakan korelasi} antara anggota observasi satu dengan observasi lain yang berlainan waktu. Dalam kaitannya dengan metode OLS, autokorelasi merupakan korelasi antara satu variabel gangguan dengan variabel gangguan yang lain. Apabila terjadi autokorelasi, maka estimator yang digunakan tidak mempunyai varian yang minimum lagi (no longer best). Estimator yang tidak minimum menyebabkan perhitungan standard error dan uji hipotesis tidak lagi bisa dipercaya. Uji autokorelasi dalam penelitian ini menggunakan metode Durbin Watson (DW). Uji statistik Durbin Watson didasarkan dari residual metode OLS (Widarjono, 2010). 
3. Heteroskedastisitas

Heteroskedastisitas merupakan masalah yang disebabkan varian variabel gangguan adalah tidak konstan. Heteroskedastisitas menyebabkan estimator tidak lagi mempunyai varian yang minimum (no longer) walaupun estimator metode OLS masih linear dan masih tidak bias. Uji heteroskedastisitas dalam penelitian ini menggunakan uji White dimana metode yang tidak memerlukan asumsi tentang adanya normalitas pada variabel gangguan. Uji White didasarkan pada jumlah sampel dikalikan dengan $\mathrm{R}^{2}$ yang akan mengikuti distribusi chisquares dengan degree of freedom sebanyak variabel independen tidak termasuk dalam regresi auxiliary. Nilai hitung chi suares $\left(\chi^{2}\right)$ dapat dicari dengan formula sebagai berikut (Widarjono, 2010) :

$\mathrm{n} \mathrm{R}^{2} \approx \chi_{\mathrm{df}}^{2}$

Apabila nilai chi suare hitung (n $\mathrm{R}^{2}$ ) lebih besar dari nilai $\chi^{2}$ kritis dengan derajat kepercayaan tertentu atai probabilitas chi squares lebih kecil dari $\alpha=5 \%$ maka ada heteroskedastisitas dan sebaliknya.

\section{HASIL PENELITIAN DAN}

\section{PEMBAHASAN}

\section{Kebijakan Perberasan Vietnam}

Ekonomi perberasan di Vietnam berkembang pesat pasca eformasi "Doi Moi" pada tahun 1986. Vietnam mulai meninggalkan sistem ekonomi sosialnya dan mengadopsi sistem kapitalis dengan melakukan impor input untuk menghasilkan output yang berorientasi pada produk yang bernilai ekonomi dan memberikan izin masuknya investasi asing.

Reformasi di Vietnam dilakukan dengan transformasi berupa desentralisasi pengambilan keputusan ekonomi, memperluas partisipasi sektor swasta dalam perekonomian nasional, mengurangi kontrol harga pangan dan komoditas lainnya, mendevaluasi nilai tukar, menaikkan suku bunga di atas tingkat inflasi domestik dan meningkatkan aspek-aspek lain kebijakan makroekonomi. Liberalisasi harga merupakan aspek utama dari reformasi ekonomi di Vietnam. Sebelum tahun 1989, Vietnam menerapkan sistem harga ganda untuk komoditas beras yakni harga resmi dan harga pasar. Harga resmi merupakan harga beras saat produsen menjual beras ke negara. Harga resmi jauh lebih rendah dari harga pasar yang berlaku. Harga resmi kemudian dihapus pada tahun 1988 sehingga pada tahun yang sama harga pasar beras mampu mencapai sembilan kali harga resmi yakni harga pasar adalah 450 dong/kg sedangkan harga resmi adalah 50 dong/kg. Dengan kenaikan harga tersebut, produksi beras pada tahun 1989 meningkat 12 persen daripada tahun 1988 (Riedel dan Comer cit Bautista 1999). Kebijakan perdagangan beras di Vietnam sejak 1989 lebih menekankan tidak ada pengenaan pajak ekspor langsung karena tarif pajak ekspor untuk beras hanya 1 persen tetapi melakukan pembatasan kuantitas ekspor kuantitatif. Jumlah total ekspor beras ditentukan oleh pemerintah pusat berdasarkan proyeksi produksi dan konsumsi. Kebijakan lain yang diambil Vietnam antara lain (Mohsin cit Suryana dan Ketut, 2008), pertama, sejak tahun 2001 pemerintah menyediakan lahan pertanian yang dapat digunakan petani dan masyarakat miskin tanpa dibebani sewa. Kedua, pemerintah menjamin tingkat keuntungan tertentu petani padi dengan membeli semua beras yang ada di pasar jika harga jatuh. Ketiga, sejak tahun 2001 pemerintah Vietnam membuat kebijakan pemberian subsidi bunga pinjaman. Kebijakan perberasan Vietnam lainnya disajikan tabel 3. 
Tabel 3 Matriks Kebijakan Perberasan di Vietnam

\begin{tabular}{|c|c|c|c|c|}
\hline Negara & $\begin{array}{c}\text { Harga } \\
\text { Domestik } \\
(\mathrm{Rp} / \mathrm{kg})\end{array}$ & $\begin{array}{c}\text { Produksi } \\
\text { terhadap } \\
\text { Konsumsi }(\%)\end{array}$ & Kebijakan Perberasan & Kesimpulan \\
\hline Vietnam & 2.800 & 120 & $\begin{array}{l}\text { Reservasi lahan irigasi } \\
\text { Kebijakan bebas pajak atau } \\
\text { subsidi untuk impor benih } \\
\text { Kebijakan pajak impor pupuk } \\
\text { dan pestisida yang kecil } \\
\text { Kebijakan harga dasar } \\
\text { Investasi publik pembangunan } \\
\text { sarana dan prasarana irigasi } \\
\text { Investasi publik pada } \\
\text { pengolahan dan perguảangan } \\
\text { modern } \\
\text { Kebijakan harga ekspor }\end{array}$ & $\begin{array}{lr}\text { Menerapkan } & \text { kebijakan } \\
\text { perberasan pro petani yang } \\
\text { ditujukan } \\
\text { meningkatkan } \\
\text { melalui kebijakan harga dan } \\
\text { non harga }\end{array}$ \\
\hline
\end{tabular}

Sumber : Syafaat cit Suswono (2008)

Analisis tren pertumbuhan ekspor beras digunakan untuk melihat kinerja ekspor sehingga mencerminkan perubahan jangka panjang dari produk bersangkutan. Sementara itu, analisis tren pertumbuhan impor beras digunakan untuk melihat perkembangan impor beras suatu negara. Selanjutnya, analisis tren digunakan untuk memprediksi prospek ke depan untuk komoditas beras tiap negara dengan asumsi kondisi internal dan eksternal tetap mendukung.

Ekspor beras dunia mengalami penurunan akibat terjadinya fenomena El Nino tahun 1972-1973 dan La Nina tahun 1973-1974 dan 1975-1976. Thailand mengurangi ekspornya sampai $10 \%$ guna mencukupi kebutuhan kebutuhan dalam negerinya, sementara Kamboja dan Vietnam Selatan sama sekali keluar dari pasar beras dunia. Sejak pertengahan 80'an sampai dengan 90'an, kondisi pasar beras dunia mulai membaik yang ditandai dengan kenaikan ekspor beras Thailand hingga $40 \%$ dari produksi dalam negerinya.

\section{Tren Ekspor dan Impor Beras Vietnam}

Reformasi tanah merupakan kebijakan yang mewarnai perberasan di Vietnam pada tahun 1981 dan 1988. Pingali dan Xuan cit Nielsen (2002), memberikan gambaran tentang reformasi tanah yang terjadi pada tahun 1981 yakni sistem kontrak dimana petani diwajibkan melakukan perjanjian dengan ditunjuk koperasi untuk menghasilkan tingkat output tertentu di tanah pribadi dan kemudian harus dijual kepada negara. Koperasi ini pada gilirannya akan memberikan input yang diperlukan petani. Namun sistem kontrak terbukti tidak berhasil karena sistem ini dilakukan oleh Perencanaan Negara Komisi secara top down tanpa pertimbangan petani dan kondisi pasar lokal serta kurangnya keamanan kepemilikan lahan menyebabkan suboptimal pertanian tingkat investasi dalam produktivitas lahan. Reformasi berikutnya pada tahun 1988, 1993 dan 1997 telah berusaha untuk mengatasi kekurangan dari reformasi tanah awal terutama masalah kekurangan insentif untuk berinvestasi dalam produktivitas lahan. Kebijakan lainnya adalah subsidi pupuk yang telah meningkatkan penggunaan pupuk kimia dalam produksi padi dimana pada tahun 1983-1985 dari $57 \mathrm{~kg} / \mathrm{ha}$ meningkat menjadi $200 \mathrm{~kg} / \mathrm{ha}$ pada tahun 1996 serta meningkatkan intensitas tanam produksi beras (Minot and Francesco cit Nielsen, 2002). 
Analisis tren pertumbuhan ekspor beras digunakan untuk melihat kinerja ekspor sehingga mencerminkan perubahan jangka panjang dari produk bersangkutan. Sementara itu, analisis tren pertumbuhan impor beras digunakan untuk melihat perkembangan impor beras suatu negara. Selanjutnya, analisis tren digunakan untuk memprediksi prospek ke depan untuk komoditas beras tiap negara dengan asumsi kondisi internal dan eksternal tetap mendukung.

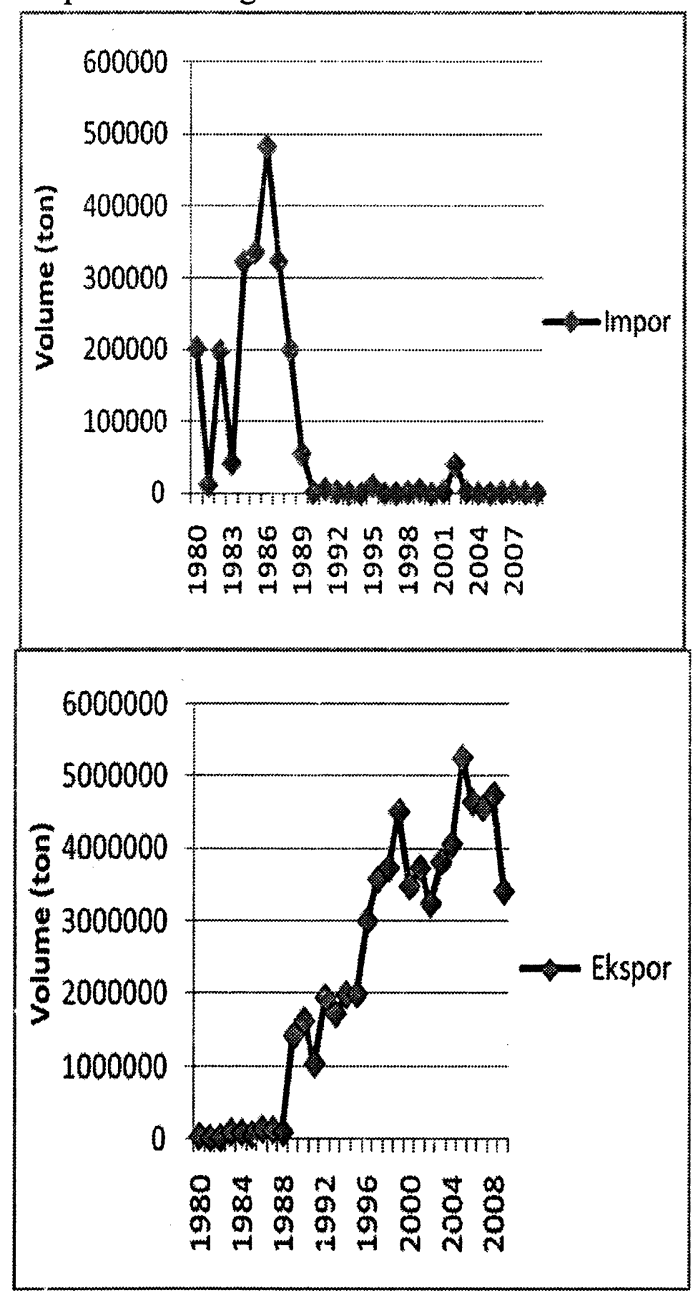

Sumber : FAO (2012)

Gambar 2 Tren Ekspor dan Impor Beras

Vietnam Tahun 1980-2009
Kegiatan ekspor beras di Vietnam dikendalikan oleh dua BUMN yakni VINAFOOD I (perusahaan makanan bagian utara) di Hanoi dan VINAFOOD II (perusahaan makanan bagian selatan) di Ho Chi Minh. Tren ekspor Vietnam menunjukkan persamaan $\mathrm{Y}=-711.578,391+192.329,273 \mathrm{~T}$. Hal ini menunjukkan bahwa ekspor beras Vietnam meningkat sebesar $192.329,273$ ton per tahun. Sedangkan tren impor Vietnam adalah $\mathrm{Y}=215.122,651-9.045,388 \mathrm{~T}$. Hal ini menunjukkan bahwa Vietnam pada awalnya merupakan negara importir namun kemudian volume impornya terus menurun dengan jumlah 9.045,388 ton per tahun.

Pada awal tahun 80'an Vietnam merupakan negara importir beras, namun mendekati akhir tahun 80'an Vietnam mampu menjadi negara eksportir beras. Menurut Minot dan Francesco (1998), keberhasilan Vietnam menjadi eksportir beras dimulai pada akhir 80 'an. Vietnam mulai melakukan peningkatan produksi melalui investasi irigasi dan penggunaan benih unggul berumur hasil lebih pendek dan berdaya hasil tinggi, Reformasi ini mendorong peningkatan produksi beras mencapai 19\% selama periode 1986-1989. Vietnam mulai mengekspor beras pada tahun 1989 dan telah berada di antara tiga eksportir beras terbesar saat itu. Selain itu, ada beberapa kebijakan di Vietnam yang mendukung kondisi ekspor beras. Menurut Cuc (1995), kebijakan pemerintah berupa Resolusi No. 10 Tahun 1988 dimana peran koperasi mengalokasikan tanah kepada petani dalam bentuk sewa jangka panjang dan petani diperbolehkan menjual surplus berasnya di pasar bebas merupakan penyebab kemajuan ekspor di Vietnam. Pada tahun 1989, liberalisasi perdagangan dan kebijakan devaluasi meningkatkan insentif untuk memproduksi barang, termasuk beras, untuk ekspor. 
Kualitas beras yang diekspor oleh Vietnam telah meningkat sejak tahun 1989. Pada awal 90'an, Vietnam mengekspor beras kualitas rendah dengan harga murah, namun kemudian kualitas ekspor beras Vietnam mengalami peningkatan. Jumlah ekspor beras berkualitas baik (0-5 \% mudah rusak) telah berkembang dari $1 \%$ menjadi sekitar $30 \%$ dalam beberapa tahun terakhir. Selama periode yang sama, jumlah ekspor beras berkualitas rendah (35\% dan lebih tinggi persentase rusak) telah menurun dari $88 \%$ menjadi $9 \%$. Peningkatan kualitas beras merupakan hasil dari perbaikan pemrosesan. Negara tujuan ekspor beras dari Vietnam antara lain Kuba, Indonesia, Irak, Malaysia, dan beberapa negara Afrika (Minot and Fransesco, 1998).

Kecenderungan perdagangan tiap negara dari waktu ke waktu akan memperlihatkan seberapa besar selisih ekspor dan impor atau lebih dikenal dengan net ekspor. Nilai net ekspor tersaji pada gambar 2.

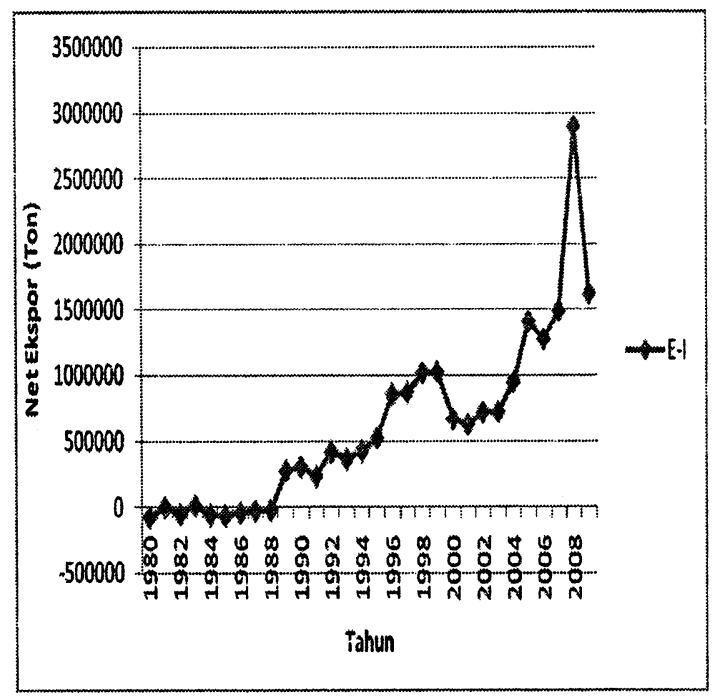

Sumber : Analisis Data Sekunder (2012) Gambar 3 Net Ekspor Vietnam Tahun 19802009
Ekspor beras Vietnam menunjukkan suatu kemajuan sangat pesat dengan laju pertumbuhan ekspor sangat tinggi bahkan melebihi Thailand. Hal ini disebabkan produktivitas lahan (diukur dari volume produksi per hektar lahan) Vietnam sudah melampaui Thailand yakni sekitar 1,7 kali dibandingkan Thailand. Sementara, biaya produksi beras Vietnam lebih kompetitif yakni US\$ 220 per ton sementara Thailand sebesar US\$ 250 per ton. Dengan laju pertumbuhan yang cukup tinggi ini, maka ke depan pangsa ekspor beras Vietnam di pasar regional maupun global akan meningkat dengan laju yang lebih pesat dibandingkan Thailand.

\section{Trade Specialization Ratio (TSR)}

TSR menunjukkan tahap ekspor komoditas dunia di pasar dunia. Indeks TSR mempertimbangkan sisi suplai domestik dan permintaan domestik.

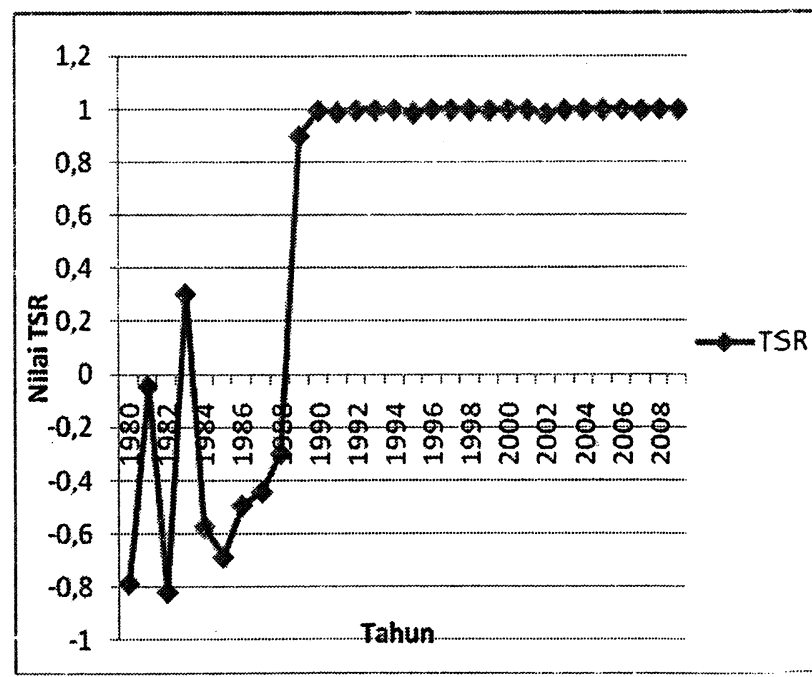

Sumber : Analisis Data Sekunder (2012)

Gambar 4 TSR Beras Vietnam 1982-2009

TSR Vietnam pada awal tahun awal 80'an bernilai rendah karena kuantitas ekspor lebih besar dari kuantitas impor. Pada 
pertengahan tahun 80 'an, TSR Vietnam mulai naik dan mampu menjadi subtitusi impor karena ada reformasi Doi Moi sehingga terjadi peningkatan produksi walaupun tidak cukup tinggi untuk mencapai skala ekonominya (optimal). Pada tahap selanjutnya, Vietnam mampu melakukan perluasan ekspor dimana produksi meningkat dalam skala yang besar sedangkan di pasar domestik penawaran lebih besar daripada permintaan untuk beras.

\section{Revealed Comparative Advantage (RCA)}

Indeks RCA digunakan untuk membandingkan posisi daya saing komoditas beras Vietnam dengan produsen lain di pasar internasional dengan asumsi faktor-faktor yang mempengaruhi pertumbuhan ekspor tidak berubah. Semakin besar nilai RCA maka semakin tinggi pula daya saing komoditas negara tersebut.

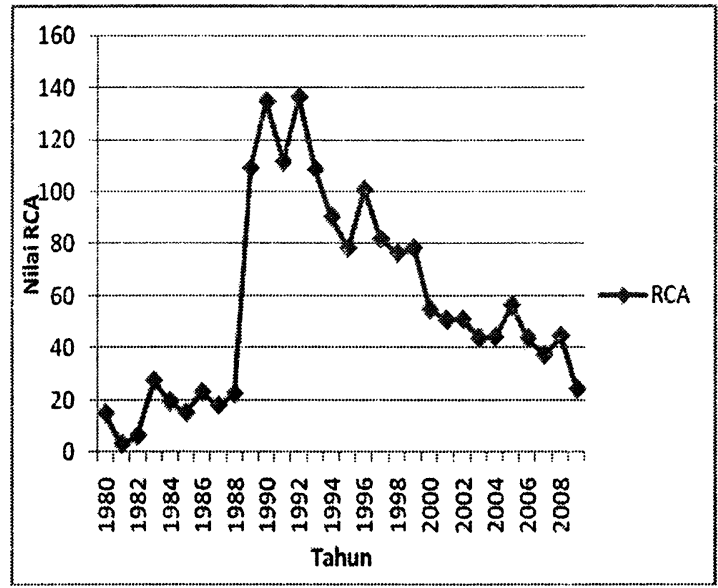

Sumber : Analisis Data Sekunder (2012)

Gambar 5 RCA Beras Vietnam 1982-2009

Vietnam memiliki indeks RCA sangat tinggi sehingga memiliki memiliki keunggulan kompetitif terhadap komoditas beras di pasar internasional. Indeks RCA beras Vietnam yng tinggi disebabkan kebijakan berupa subsidi, pembangunan fasilitas pertanian dan pemakaian teknologi maju dalam pengelolaan usahatani dan pasca panen komoditas padi. Pada tahun $80^{\prime}$ an, daya saing beras Thailand lebih baik dari beras Vietnam. Namun memasuki tahun 90'an, daya saing beras Vietnam menjadi lebih baik dari beras Thailand. Keunggulan beras Vietnam atas Thailand salah satunya dipengaruhi oleh produktivitas lahan Vietnam sudah melampaui Thailand dan biaya produksi beras Vietnam lebih kompetitif daripada beras Thailand sehingga permintaan impor beras dari Vietnam lebih besar daripada beras Thailand. Harga beras wangi Vietnam dijual US\$ 650 per ton atau US\$ 400-500 lebih murah dari beras hom mali dari Thailand serta lebih rendah US\$ 150200 dari beras Pathum Thani. Apabila dilihat dari kontribusi kuantitas ekspor beras terhadap perdagangan beras dunia, saat ini Thailand masih lebih unggul daripada Vietnam, namun dengan melihat perkembangan RCA dalam beberapa tahun terakhir maka bukan tidak mungkin ke depan beras Vietnam akan mendominasi perdagangan beras dunia.

\section{Acceleration Ratio}

Nilai acceleration ratio (AR) menunjukkan apakah suatu negara dapat merebut pasar di luar negeri atau posisinya lemah di pasar ekspor atau pasar domestik. Indeks AR lebih melihat proses dinamika jangka panjang dimana nilai AR beras Vietnam adalah 0,635 sehingga percepatan ekspor beras Vietnam lebih lambat daripada pertumbuhan volume ekspor beras di tingkat dunia. Nilai AR yang lebih kecil dari 1 sementara TSR bernilai 1 dapat dimaknai bahwa keunggulan komoditas beras Vietnam dalam perdagangan internasional sudah mengalami penurunan. 


\section{Uji Asumsi Klasik}

\section{a Multikoliniearitas}

Uji multikoliniearitas digunakan untuk mengetahui hubungan antar variabel independen. Permasalahan multikoliniearitas dilakukan dengan mencari nilai hubungan korelasi antar variabel independen. Apabila nilai korelasi lebih dari 0,8 menunjukkan bahwa pada persamaan regresi terjadi multikoliniearitas.

Tabel 4 Hasil Uji Multikolinieritas

\begin{tabular}{cc}
\hline Kegiatan & Kesimpulan \\
\hline Impor & Terjadi Mulikoliniearitas \\
Ekspor & Tidak ada Mulikoliniearitas \\
\hline
\end{tabular}

Sumber : Analisis Data Sekunder (2012)

Hasil analisis menunjukkan bahwa pada analisis regresi impor Vietnam terjadi kasus multikoliniearitas antara pendapatan per kapita dengan ketersediaan beras per kapita sehingga diperlukan modifikasi dalam persanaan regresi. Variabel pendapatan per kapita dimodifikasi menjadi pendapatan riil yakni pendapatan per kapita dikalikan jumlah penduduk dibagi harga beras impor. Modifikasi ini juga menimbulkan implikasi dimana variabel ketersediaan per kapita beras berubah menjadi produksi karena variabel jumlah penduduk telah masuk dalam variabel pendapatan total. Modifikasi ini merupakan persamaan regresi yang bebas multikoliniearitas.

\section{b Heteroskedastisitas}

Untuk mengetahui ada tidaknya masalah heteroskedastisitas dalam penelitian ini digunakan uji White. Kriteria suatu persamaan regresi dikatakan memiliki masalah heteroskedastisitas apabila nilai probabilitas $R^{2}$ uji White lebih kecil dari nilai kritis pada taraf $\alpha=5 \%(0,05)$.
Tabel 5 Hasil Uji Heteroskedastisitas

\begin{tabular}{|c|c|c|}
\hline Kegiatan & Nilai Uji White & Kesimpulan \\
\hline Impor & 0,640395 & $\begin{array}{c}\text { Tidak ada } \\
\text { Heteroskedastisitas }\end{array}$ \\
\hline Ekspor & 0,193110 & $\begin{array}{c}\text { Tidak ada } \\
\text { Heteroskedastisitas }\end{array}$ \\
\hline
\end{tabular}

Sumber : Analisis Data Sekunder (2012)

Hasil analisis dengan uji White terhadap persamaan yang digunakan dalam penelitian ini menunjukkan bahwa tiap model yang digunakan telah bebas dari masalah heteroskedastisitas. Hal ini berarti model yang digunakan dalam penelitian akan memenuhi asumsi BLUE.

\section{c Autokorelasi}

Untuk mengetahui ada tidaknya masalah autokorelasi dalam penelitian ini digunakan uji Durbin Watson. Hampir semua program statistik sudah menyediakan fasilitas untuk menghitung $d$ (yang menggambarkan koefisien DW). Nilai d akan berada di kisaran 0 hingga 4. Dengan melihat hasil analisis data maka dapat diketahui ada tidaknya autokorelasi seperti dimuat pada tabel 6 .

\begin{tabular}{|c|c|c|c|}
\hline \multirow{4}{*}{ Impor } & Jangka & 1,63 & Tidak ada \\
\hline & Pendek & & Aurokorelasi \\
\hline & Jangka & 1,81 & Tidak ada \\
\hline & Panjang & & Autokorelasi \\
\hline \multirow[t]{3}{*}{ Ekspor } & Jangka & 1,59 & Tidak ada \\
\hline & Pendek & & Autokorelasi \\
\hline & $\begin{array}{l}\text { Jangka } \\
\text { Panjang }\end{array}$ & 1,52 & $\begin{array}{l}\text { Tidak dapat } \\
\text { disimpulkan }\end{array}$ \\
\hline
\end{tabular}

Sumber : Analisis Data Sekunder (2012)

Hasil analisis Durbin Watson menunjukkan bahwa tiap model yang digunakan tidak ada yang mengalami masalah autokorelasi. Hal ini berarti model yang digunakan dalam penelitian akan memenuhi asumsi BLUE. 
Faktor yang Mempengaruhi Ekspor dan Impor Beras Vietnam

\section{a) Ekspor}

Uji akar unit ekspor beras Vietnam menunjukkan bahwa variabel yang signifikan pada $\alpha=5 \%$ adalah ekspor, harga beras dunia, nilai tukar dan efisiensi input produksi.
Sedangkan variabel yang tidak signifikan pada $\alpha=5 \%$ adalah ketersediaan beras per kapita Vietnam, harga ekspor beras dan dummy AFTA. Dengan adanya variabel belum stasioner pada derajat nol, maka perlu dilakukan uji stasioneritas lagi dengan menggunakan uji derajat integrasi satu

Tabel 7 Uji Stasioner Data Derajat Nol Ekspor Beras Vietnam

\begin{tabular}{lcccc}
\hline Variabel & Uji & Nilai Probabilitas & Nilai Kritis & Kesimpulan \\
\hline Ekspor & DF & 0,0118 & 0,05 & Signifikan \\
Ketersediaan & DF & 0,2404 & 0,05 & Tidak Signifikan \\
Hrg ekspor & DF & 0,1426 & 0,05 & Tidak Signifikan \\
Hrg dunia & DF & 0,0291 & 0,05 & Signifikan \\
Nilai tukar & DF & 0,0468 & 0,05 & Signifikan \\
Efisiensi input produksi & DF & 0,0024 & 0,05 & Signifikan \\
AFTA & DF & 0,7835 & 0,05 & Tidak Signifikan \\
\hline
\end{tabular}

Sumber : Analisis Data Sekunder (2012)

Variabel ekspor, ketersediaan beras per kapita, harga beras ekspor, harga beras dunia, nilai tukar, efisiensi input produksi dan dummy AFTA telah stasioner pada derajat satu, yang ditunjukkan dari nilai probabilitas DF yang lebih kecil dibandingkan nilai kritisnya (Mackinnon critical values) pada $\alpha=5 \%$. Tahap selanjutnya yang dilakukan setelah data stasioner adalah uji kointegrasi

Tabel 8 Uji Stasioner Data Derajat Integrasi Tingkat Pertama Ekspor Beras Vietnam

\begin{tabular}{lcccc}
\hline Variabel & Uji & Nilai Probabilitas & Nilai Kritis & Kesimpulan \\
\hline Ekspor & DF & 0,0000 & 0,05 & Signifikan \\
Ketersediaan & DF & 0,0000 & 0,05 & Signifikan \\
Hrg Ekspor & DF & 0,0001 & 0,05 & Signifikan \\
Hrg Dunia & DF & 0,0068 & 0,05 & Signifikan \\
Nilai Tukar & DF & 0,0001 & 0,05 & Signifikan \\
Efisiensi input produksi & DF & 0,0000 & 0,05 & Signifikan \\
AFTA & DF & 0,0012 & 0,05 & Signifikan \\
\hline
\end{tabular}

Sumber : Analisis Data Sekunder (2012)

Hasil uji kointegrasi untuk ekspor beras Vietnam menunjukkan bahwa terjadi kointegrasi antara variabel dependen dengan variabel independen sehingga terdapat hubungan jangka panjang antara variabel dependen dengan variabel independen. 
Tabel 9 Uji Kointegrasi Ekspor Beras Vietnam

\begin{tabular}{ccccc}
\hline $\begin{array}{c}\text { Hypothesized No. of } \\
\text { CE }(s)\end{array}$ & Eigenvalue & Trace Statistic & $\begin{array}{c}\text { 5 Percent Critical } \\
\text { Value }\end{array}$ & $\begin{array}{c}\text { 1 Percent Critical } \\
\text { Value }\end{array}$ \\
\hline None ** & 0,942344 & 201,3806 & 124,24 & 133,57 \\
At most 1 ** & 0,841888 & 121,4893 & 94,15 & 103,18 \\
At most 2 & 0,672875 & 69,84477 & 68,52 & 76,07 \\
At most 3 & 0,510171 & 38,55720 & 47,21 & 54,46 \\
At most 4 & 0,324777 & 18,57362 & 29,68 & 35,65 \\
At most 5 & 0,235642 & 7,577698 & 15,41 & 20,04 \\
At most 6 & 0,001911 & 0,053559 & 3,76 & 6,65 \\
\hline
\end{tabular}

Sumber : Analisis Data Sekunder (2012)

Hasil estimasi ekspor Vietnam model regresi dinamis dengan ECM dimana model regresi ini dapat dioptimalisasikan setelah memenuhi persyaratan stasioneritas data disajikan tabel 10.

Tabel 10 Estimasi Ekspor Beras Vietnam Model Regresi Dinamis dengan ECM

\begin{tabular}{ccccc}
\hline Variabel & \multicolumn{2}{c}{ Jangka pendek } & \multicolumn{2}{c}{ Jangka panjang } \\
\cline { 2 - 5 } & Coefficient & Prob. & Coefficient & Prob. \\
\hline C & 0,017626 & 0,7198 & 8,103645 & 0,0000 \\
D(LOGKETERSEDIAAN) & 4,512498 & $0,0822^{* *}$ & 4,230333 & $0,0009^{*}$ \\
D(LOGHRGEKSPOR) & $-2,137963$ & $0,0003 *$ & $-1,334504$ & 0,1008 ts \\
D(LOGHRGDUNIA) & 1,638924 & $0,0183^{*}$ & 0,924936 & 0,2253 ts \\
D(LOGNILATUKAR) & 0,123636 & 0,3217 ts & 0,279082 & $0,0001^{*}$ \\
D(LOGEFISIENSI) & 0,017400 & 0,5809 ts & 0,014998 & 0,7359 ts \\
D(AFTA) & $-0,035411$ & 0,8648 ts & $-0,012296$ & 0,9456 ts \\
RESID01(-1) & $-0,866140$ & $0,0005^{*}$ & & \\
\hline Adjusted R-squared & & 0,568555 & Adjusted R-squared & 0,935721 \\
Durbin-Watson stat & & 1,595741 & Durbin-Watson stat & 1,523196 \\
Prob(F-statistik) & & 0,000471 & Prob(F-statistik) & 0,000000 \\
\hline Sund
\end{tabular}

Sumber: Analisis Data Sekunder (2012)

Keterangan :

*signitikan pada taraf $5 \%$

** signifikan pada taraf $10 \%$

ts tidak signifikan

Model analisis ekspor beras Vietnam jangka pendek memiliki koefisien determinasi 0,5685 sehingga $56,85 \%$ variasi ekspor beras Vietnam dapat dijelaskan oleh variasi variabel independen sedangkan untuk jangka panjang merupakan model yang baik dengan koefisien determinasi 0,9357 sehingga $93,57 \%$ variasi ekspor beras Vietnam dapat dijelaskan oleh variasi variabel independen. Berdasarkan uji $f$ diketahui bahwa nilai probabilitas $f$ statistik bernilai lebih kecil dari 0,05 sehingga variabel independen secara bersama berpengaruh nyata terhadap ekspor beras Vietnam.

Variabel ECT berpengaruh signifikan pada tingkat signifikansi $95 \%$. Hal ini memperkuat bukti adanya hubungan kointegrasi atau hubungan jangka panjang atau keseimbangan antara variabel ekspor beras Vietnam dengan variabel independen. Selain itu, signifikansi variabel ECT juga berarti bahwa model empiris yang digunakan dalam penelitian memiliki spesifikasi model yang valid sehingga hasil estimasi dapat digunakan 
untuk melihat pengaruh variabel independen terhadap volume ekspor beras Vietnam

Hasil analisis uji parsial faktor-faktor yang mempengaruhi ekspor beras Vietnam sebagai berikut :

1) Ketersediaan beras per kapita

Ketersediaan beras per kapita Vietnam berpengaruh signifikan terhadap ekspor beras Vietnam dalam jangka pendek maupun jangka panjang. Apabila ketersediaan beras per kapita Vietnam meningkat $1 \%$ maka volume ekspor beras Vietnam akan meningkat $4,51 \%$ pada jangka pendek dan $4,23 \%$ pada jangka panjang. Dengan adanya peningkatan ketersediaan beras domestik, maka Vietnam akan mampu meningkatkan ekspor beras. Kebijakan peningkatan produksi Vietnam merupakan salah satu pendorong dalam dua dekade terakhir sehingga Vietnam mampu meningkatkan ekspor berasnya.

2) harga ekspor beras Vietnam

Harga beras ekspor Vietnam berpengaruh nyata terhadap volume ekspor beras Vietnam untuk jangka pendek namun tidak berpengaruh signifikan pada jangka panjang. Dalam jangka pendek, apabila harga beras ekspor Vietnam naik $1 \%$ maka volume ekspor beras yang ditawarkan turun 2,13\%. Kondisi ini merupakan indikasi yang umum dalam perekonomian. Apabila ada kenaikan harga maka permintaan impor beras Vietnam akan turun. Adanya penurunan permintaan impor dari negara lain akan disikapi Vietnam dengan mengurangi ekspor beras dan menjual produknya di dalam negeri.

3) Harga beras dunia fob Thailand Harga beras dunia fob Thailand berpengaruh signifikan terhadap ekspor beras Vietnam untuk jangka pendek yakni apabila harga beras dunia meningkat $1 \%$ maka volume ekspor beras Vietnam meningkat $1,18 \%$. Hal ini terjadi karena harga beras Vietnam akan bernilai lebih rendah dari harga dunia sehingga permintaan ekspor beras Vietnam akan meningkat dengan pertimbangan harga beras ekspor Vietnam lebih rendah dari harga dunia. Kenaikan harga dunia akan meningkatkan keuntungan yang diterima oleh pengekspor dalam negeri Vietnam sehingga akan meningkatkan volume ekspornya. Untuk jangka panjang, harga beras dunia tidak berpengaruh signifikan terhadap volume ekspor beras Vietnam.

4) Nilai tukar dollar AS terhadap dong

Nilai tukar dollar AS terhadap dong tidak berpengaruh signifikan terhadap volume ekspor beras Vietnam pada jangka pendek namun berpengaruh signifikan pada jangka panjang. Apabila nilai tukar dollar AS terhadap dong meningkat $1 \%$ maka volume ekspor beras Vietnam meningkat $0,27 \%$. Vietnam merupakan eksportir beras terbesar kedua di dunia sehingga pada saat nilai tukar melemah maka eksportir 
akan mengekspor beras dalam jumlah lebih besar karena jumlah uang yang diterima lebih banyak pula.

5) Efisiensi input produksi

Efisiensi input produksi Vietnam tidak berpengaruh signifikan terhadap volume ekspor beras Vietnam baik dalam jangka pendek maupun jangka panjang. Hal ini terjadi karena selama ini Vitenam telah mampu melakukan efisiensi penggunaan input.

6) Dummy AFTA

Volume ekspor beras Vietnam jangka pendek maupun jangka panjang tidak dipengaruhi kebijakan AFTA. Hal ini terjadi karena sebelum pemberlakuan AFTA, Vietnam merupakan salah satu negara yang unggul dalam perdagangan beras sehingga pemberlakuan AFTA tidak akan mengubah volume ekspor beras.

\section{b) Impor}

Uji akar unit impor beras Vietnam menunjukkan bahwa variabel yang signifikan pada $\alpha=5 \%$ adalah impor, harga beras dunia, pendapatan riil, nilai tukar dan efisiensi input produksi. Sedangkan variabel yang tidak signifikan pada $\alpha=5 \%$ adalah produksi dan dummy AFTA. Dengan adanya banyak variabel belum stasioner pada derajat nol, maka perlu dilakukan uji stasioneritas lagi dengan menggunakan uji derajat integrasi satu.

Tabel 11 Uji Stasioner Data Derajat Nol Impor Beras Vietnam

\begin{tabular}{llccc}
\hline Variabel & Uji & Nilai Probabilitas & Nilai Kritis & Kesimpulan \\
\hline Impor & DF & 0,0470 & 0,05 & Signifikan \\
Produksi & DF & 0,0995 & 0,05 & Tidak Signifikan \\
Hrg dunia & DF & 0,0291 & 0,05 & Signifikan \\
GNP riil & DF & 0,0042 & 0,05 & Signifikan \\
Nilai tukar & DF & 0,0468 & 0,05 & Signifikan \\
Efisiensi input produksi & DF & 0,0024 & 0,05 & Signifikan \\
AFTA & DF & 0,7835 & 0,05 & Tidak Signifikan \\
\hline
\end{tabular}

Sumber : Analisis Data Sekunder (2012)

Variabel impor, produksi, harga beras dunia, pendapatan riil, nilai tukar, efisiensi input produksi dan dummy AFTA telah stasioner pada derajat satu, yang ditunjukkan dari nilai probabilitas DF yang lebih kecil dibandingkan nilai kritisnya (Mackinnon critical values) pada $\alpha=5 \%$. Tahap selanjutnya yang dilakukan setelah data stasioner adalah uji kointegrasi.

Tabel 12 Uji Stasioner Data Derajat Integrasi Tingkat Pertama Impor Beras Vietnam

\begin{tabular}{llccc}
\hline Variabel & Uji & Nilai Probabilitas & Nilai Kritis & Kesimpulan \\
\hline Impor & DF & 0,0000 & 0,5 & Signifikan \\
Produksi & DF & 0,0001 & 0,05 & Signifikan \\
Hrg dunia & DF & 0,0068 & 0,05 & Signifikan \\
GNP riil & DF & 0,0000 & 0,05 & Signifikan \\
Nilai tukar & DF & 0,0001 & 0,05 & Signifikan \\
Efisiensi input produksi & DF & 0,0000 & 0,05 & Signifikan \\
AFTA & DF & 0,0012 & 0,05 & Signifikan \\
\hline
\end{tabular}

Sumber : Analisis Data Sekunder (2012) 
Hasil uji kointegrasi untuk impor beras Vietnam menunjukkan bahwa terjadi kointegrasi antara variabel dependen dengan variabel independen sehingga terdapat hubungan jangka panjang antara variabel dependen dengan variabel independen.

Tabel 13 Uji Kointegrasi Impor Beras Vietnam

\begin{tabular}{|c|c|c|c|c|}
\hline $\begin{array}{c}\text { Hypothesized No. of } \\
\qquad E(s)\end{array}$ & Eigenvalue & T'race Statistic & $\begin{array}{c}5 \text { Perceni Critical } \\
\text { Value }\end{array}$ & $\begin{array}{c}1 \text { Perceni Critical } \\
\text { Value }\end{array}$ \\
\hline None $* *$ & 0,880215 & 182,7467 & 124,24 & 133,57 \\
\hline At most $1 * *$ & 0,810994 & 123,3290 & 94,15 & 103,18 \\
\hline At most 2 & 0,759335 & 76,68174 & 68,52 & 76,07 \\
\hline At most 3 & 0,460456 & 36,80000 & 47,21 & 54,46 \\
\hline At most 4 & 0,364710 & 19,52314 & 29,68 & 35,65 \\
\hline At most 5 & 0,195778 & 6,820294 & 15,41 & 20,04 \\
\hline At most 6 & 0,025374 & 0,719643 & 3,76 & 6,65 \\
\hline
\end{tabular}

Sumber : Analisis Data Sekunder (2012)

Hasil estimasi impor Vietnam model regresi dinamis dengan ECM dimana model memenuhi persyaratan stasioneritas data regresi ini dapat dioptimalisasikan setelah disajikan tabel 14.

Tabel 14 Estimasi Impor Beras Vietnam Model Regresi Dinamis dengan ECM

\begin{tabular}{ccccc}
\hline Variabel & \multicolumn{2}{c}{ Jangka pendek } & \multicolumn{2}{c}{ Jangka panjang } \\
\cline { 2 - 5 } & Coefficient & Prob. & Coefticient & Prob. \\
\hline C & $-0,149086$ & 0,3343 & 39,02014 & 0,0062 \\
D(LOGPRODUKSI) & $-0,345280$ & 0,9528 ts & $-4,426531$ & $0,0133^{*}$ \\
D(LOGHRGDUNIA) & $-1,464414$ & 0,2590 ts & $-2,368106$ & $0,0523^{* *}$ \\
D(LOGGNPRII) & 0,440557 & $0,0000^{*}$ & 0,430974 & $0,0000^{*}$ \\
D(LOGNILAITUKAR) & 0,338682 & 0,3382 ts & $-0,091584$ & 0,6674 ts \\
D(LOGEFISIENSI) & $-0,099585$ & 0,7786 ts & $-0,468515$ & 0,3998 ts \\
D(AFTA) & 0,100836 & 0,8616 ts & 0,600903 & 0,2788 ts \\
RESID01(-1) & $-0,954247$ & $0,0001^{*}$ & & \\
\hline Adjusted R-squared & & 0,906845 & Adjusted R-squared & 0,874954 \\
Durbin-Watson stat & & 1,632893 & Durbin-Watson stat & 1,812338 \\
Prob(F-statistik) & & 0,000000 & Prob(F-statistik) & 0,000000 \\
\hline Sumb
\end{tabular}

Sumber : Analisis Data Sekunder (2012)

Keterangan :

*signifikan pada taraf $5 \%$

** signifikan pada taraf $10 \%$

ts tidak signifikan

Koefisien determinasi analisis faktor yang mempengaruhi impor beras Vietnam dengan model persamaan Error Correction Model (ECM) untuk periode jangka pendek bernilai 0,9068 sehingga merupakan model yang baik. Nilai koefisien determinasi menunjukkan $90,68 \%$ variasi impor beras Vietnam dijelaskan oleh variasi variabel independen. Sedangkan untuk periode jangka panjang bernilai 0,8749 sehingga $87,49 \%$ variasi impor beras Vietnam dijelaskan oleh variasi variabel independen. Berdasarkan uji $f$ 
diketahui bahwa nilai probabilitas $\mathrm{f}$ statistik bernilai lebih kecil dari 0,05 sehingga independen secara bersama berpengaruh nyata terhadap impor beras Vietnam.

Variabel ECT berpengaruh signifikan pada tingkat signifikansi 95\%. Hal ini memperkuat bukti adanya hubungan kointegrasi atau hubungan jangka panjang atau keseimbangan jangka panjang antara variabel impor beras Vietnam dengan variabel independen. Selain itu, signifikansi variabel ECT juga berarti bahwa model empiris yang digunakan dalam penelitian memiliki spesifikasi model yang valid sehingga hasil estimasi dapat digunakan untuk melihat pengaruh variabel independen terhadap volume impor beras Vietnam

Hasil analisis uji $t$ impor beras Vietnam untuk jangka pendek dan jangka panjang adalah sebagai berikut :

1) Produksi beras Vietnam

Produksi beras Vietnam tidak berpengaruh terhadap impor beras Vietnam pada jangka pendek karena nilai probabilitas sebesar 0,95 sedangkan untuk jangka panjang produksi beras Vietnam berpengaruh signifikan pada ataraf keperrcayaan $95 \%$. Ptoduksi beras Vietnam termasuk salah satu yang tertinggi di Asia Tenggara dan mampu untuk memnuhi kebutuhan dalam negeri sehingga kenaikan produksi beras Vietnam akan mampu mengurangi impor sebesar $4,43 \%$.

2) harga beras dunia fob Thailand Harga beras dunia fob Thailand berpengaruh terhadap volume impor beras Vietnam untuk jangka panjang. Pada jangka pendek. harga beras dunia fob Thailand tidak berpengaruh terhadap volume impor beras Vietnam. Sedangkan pada jangka panjang apabila harga beras dunia naik $1 \%$ maka volume impor beras Vietnam akan berkurang $2,37 \%$. Hal ini terjadi karena kenaikan harga beras dunia akan mendorong kenaikan harga beras impor Vietnam sehingga kendala pendapatan yang dihadapi konsumen Vietnam akan mendorong penurunan volume impor beras.

3) pendapatan nasional riil Vietnam Pendapatan nasional riil Vietnam berpengaruh signifikan terhadap impor beras Vietnam dalam jangka pendek dan jangka panjang. Apabila pendapataan riil naik $1 \%$ maka volume impor beras Vietnam akan meningkat $0,44 \%$ pada jangka pendek dan $0,43 \%$ pada jangka panjang. Hal ini sesuai dengan teori yang ada dimana saat pendapatan naik maka jumlah uang yang dibelanjakan akan bertambah pula.

4) nilai tukar nominal dollar AS terhadap dong

Nilai tukar nominal dollar AS terhadap dong tidak berpengaruh terhadap impor beras Vietnam dalam jangka pendek dan jangka panjang. Hal ini disebabkan jumlah impor beras Vietnam relatif kecil sehingga fluktuasi nilai tukar yang ada tidak akan mempengaruhi impor beras Vietnam.

5) dummy AFTA

Dummy AFTA tidak berpengaruh signifikan terhadap impor beras Vietnam untuk jangka pendek dan 
jangka panjang. Hal ini terjadi karena kebutuhan beras Vietnam sebagian besar dipenuhi oleh produksi dalam negeri sehingga adanya kebijakan AFTA tidak akan mempengaruhi volume impor beras yang diminta.

\section{KESIMPULAN DAN IMPLIKASI KEBIJAKAN \\ Kesimpulan}

1 Kinerja tren ekspor beras Vietnam menunjukkan peningkatan begitu pula tren impor beras Vietnam menunjukkan penurunan dengan posisi di dalam perdagangan beras sebagai net eksportir serta berdasarkan analisis TSR berada dalam tahapan kematangan.

2 Analisis daya saing berdasarkan RCA dan AR menunjukkan bahwa Vietnam memiliki daya saing yang tinggi untuk beras namun daya percepatan ekspornya rendah.

3 Faktor yang mempengaruhi ekspor beras Vietnam untuk jangka pendek adalah ketersediaan beras per kapita, harga beras ekspor dan harga beras dunia sedangkan untuk jangka panjang adalah ketersediaan beras per kapita dan nilai tukar nominal US\$ dolar terhadap dong. Untuk faktor yang mempengaruhi impor beras Vietnam untuk jangka pendek, adalah pendapatan nasional riil sedangkan untuk jangka panjang adalah produksi beras, harga beras dunia dan pendapatan nasional riil.

\section{Implikasi Kebijakan}

Pola perdagangan beras Vietnam menunjukkan lebih didominasi kegiatan ekspor daripada impor. Pemerintah Vietnam telah meliberalisasi pasar beras sejak tahun 80 'an namun sampai saat ini kontrol pemerintah masih dominan dalam pasar beras. Kebijakan pengembangan ekspor dilakukan dengan peningkatan produksi ataupun diversifikasi pangan. Upaya peningkatan produksi dilakukan pemerintah Vietnam dengan kebijakan pajak impor pupuk dan pestisida yang kecil, kebijakan harga dasar serta investasi publik pada pengolahan dan pergudangan modern. Vietnam secara khusus dapat menggunakan sistem penilaian beras berdasarkan kualitas untuk memenuhi permintaan pasar internasional. Pemerintah Vietnam juga perlu memperhatikan kebijakan diversifikasi pangan mengingat konsumsi beras per kapita Vietnam yang terus meningkat. Kebijakan yang masih menjadi masalah di Vietnam adalah subsidi input seperti benih dan pupuk. Hal ini mampu menciptakan efisiensi input di Vietnam namun dalam jangka panjang, subsidi akan membuat penggunaan input berlebihan dan usathatani padi menjadi tidak efisien lagi sehingga perlu ada peninjauan kembali pemberlakuan subsidi. Sementara itu, kebijakan AFTA tidak berpengaruh signifikan terhadap ekspor dan impor beras Vietnam.

Kebijakan moneter yang berkaitan dengan nilai tukar tiap negara memliki pengaruh yang berbeda untuk perdagangan beras tiap negara. Kebijakan moneter yang sebaiknya ditempuh negara Vietnam adalah mendorong nilai tukar cenderung melemah secara terkendali dengan asumsi akan meningkatkan ekspor. Melemahnya nilai mata uang dong tidak berpengaruh terhadap impor.

\section{DAFTAR PUSTAKA}

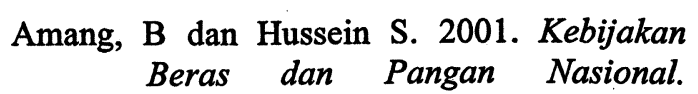


Pelajaran dari Orde Baru dan Orde Reformasi. Bogor : IPB Press

Bautista, R. 1999. The price competitiveness of rice production in vietnam: effects of domestic policies and external factors. ASEAN Economic Bulletin. XVI (1) : 80-94

Cuc, N S. 1995. Agriculture of Vietnam: 19451995. Hanoi: Statistical Publishing House

FAO, 2012. FAO Statistics. www. fao.org. Diakses tanggal 1 Oktober 2011.

Gujarati, D. 2003. Basic Econometric. New York: McGraw-Hill

Minot, A and Francesco G. 1998. Export liberalization and household welfare: the case of rice in vietnam. American Journal of Agricultural Economics. LXX (4) : 738-749

Nielsen,C.P. 2002. Vietnam's Rice Policy: Recent Reforms and Future Opportunities. Copenhagen : Danish Research Institute of Food Economics.

Salvatore, D. 1993. International Economics. New Jersey : Prentice Hall.

Sawit, H dan I.W. Rusastra. 2005. Globalisasi dan Ketahanan Pangan di Indonesia, bagian laporan penelitian Road Map Memperkuat Ketahanan Pangan. Jakarta: PEM UI

Suryana, A dan Ketut K. 2008. Ekonomi padi di Asia : suatu tinjauan berbasis kajian komparatif. Forum Penelitian Agroekonomi. XXVI (1) : 17-31

Tambunan, T.T. 2004. Globalisasi dan Perdagangan Internasional. Bogor: Ghalia Indonesia

Widarjono, A. 2010. Ekonometrika: Pengantar dan Aplikasinya. Jakarta: Ekonomi UI. 